\title{
LEAFCUTTER ANT REFUSE (ATTA MEXICANA) AS AN EXCELLENT COMPOST FOR TOMATO PRODUCTION
}

\author{
Quevedo-Martínez, E. A. - Alcántara-Mondragón, E. - Mejía-Ugalde, M. - Mejía- \\ UGALDE, I. - ÁVILA-JUÁREZ, L.
}

Biosystems Laboratory Group, Division of Graduate Studies, Faculty of Engineering, Autonomous University of Querétaro, C.U. Cerro de las Campanas S/N, Colonia Las Campanas, 9 C.P. 76010, Santiago de Querétaro, Querétaro, México

*Corresponding author

e-mail: luciano.avila@uaq.mx; phone: +52-442-192-1200; fax: +52-442-192-1200 (ext. 6006)

(Received $5^{\text {th }}$ Dec 2019; accepted $6^{\text {th }}$ May 2020)

\begin{abstract}
For hundreds of years, leafcutter ants (Atta spp.) have been cultivating the fungus Leucoagaricus gongylophorus, which grows on foraged plant biomass and subsequently serves as food for the ants. Once the biomass nutrients are depleted, mainly due to enzymatic attack by the fungus, the ants discard what we label as leafcutter ant compost (LCAC). Here, we tested whether the LCAC behaved as a compost that is capable of releasing nutrients to grow greenhouse tomato plants. Our results indicate that Atta spp. together with Leucoagaricus gongylophorus produce a mature and stable compost with a high nutrient content that is able to nourish tomato crops at a dose of $32.5 \mathrm{t} \mathrm{ha}^{-1}$. The LCAC significantly increased the organic matter content and permeability of the soil and provided soluble essential nutrients for the tomato plant, producing a yield that was not statistically different from that obtained with soluble inorganic salts without compromising the nutraceutical quality of the fruit. Our results suggest that LCAC resembles a stable compost, which immediately releases its nutrients to plants. Atta spp. play an important ecological role as they transport biomass across great distances, compost it and return it to the environment for use by neighbouring plants.
\end{abstract}

Keywords: ant compost, soluble nutrients, Leucoagaricus gongylophorus, biomass degradation, fungus garden

\section{Introduction}

Over millions of years, the ants of the genus Atta have developed a mutualistic relationship with the basidiomycete Leucoagaricus gongylophorus (Pagnocca et al., 2001; Silva-Pinhati et al., 2004), which is cultivated primarily on the leaves, stems and flowers of plant material that is located in specialized underground chambers of the ant nest (Sternberg et al., 2007). In these chambers, the basidiomycete is grown and subsequently develops hyphae that are harvested by the ants as food for themselves and their larvae (Mueller et al., 2001, 2005). Through a strict cleaning system, the workers produce symbiotic glandular and bacterial secretions to provide an aseptic environment that prevents the proliferation of parasitic fungi and unwanted microorganisms (Hölldobler and Wilson, 1990; Little et al., 2006). Through a complex process of plant material degradation, the fungus Leucoagaricus gongylophorus produces enzymes capable of degrading proteins, starch and the polysaccharides of the cell wall (Moller et al., 2011). In fact, metaproteomic analyses have identified 145 lignocellulosic enzymes, including pectinases, amylases and cellulases (Aylward et al., 2013). Once the process of decomposition and depletion of the plant material has elapsed, the worker ants dispose of it, depending on the genus, either in specialized internal waste chambers underground in the nest or, as in the genus Atta, by bringing the already decomposed material to the surface and piling it outside of the nest entrance. To obtain its food from 
the plant material, Leucoagaricus gongylophorus penetrates the leaf with its hyphae, which causes the release of nutrients such as N, Ca, Mg and K (Moutinho et al., 2003; Saha et al., 2012), among others; this process may be derived from the decomposition of organic matter. Farji-Brener and Ghermandi (2008) analysed the waste from nests of Acromyrmex lobicornis, a species of foraging ant, and found acceptable levels of organic matter, $\mathrm{N}, \mathrm{P}, \mathrm{K}, \mathrm{Ca}$ and $\mathrm{Mg}$; the values were very similar to those of commercial compost. This finding is to be expected because the leaves are one of the largest reservoirs of nutrients in the plant.

Within the underground waste chamber where plant matter decomposes in the nest, at a certain humidity and temperature that is currently unknown, the process of aerobic decomposition is very similar to the process known as "composting". The ants use these chambers as continuous bioreactors of plant matter, as they feed new substrate to the bioreactor (the "fungal garden") in the upper part of the chamber where the fresh plant material is found, and they remove the digested plant material that is commonly found in the stratum below the fungal garden. This has been confirmed by studies of enzymatic activity of the waste from above, in the middle of and at the bottom of a fungal garden (Bot et al., 2001; Hart, 2002; Moller et al., 2011; Schiøtt et al., 2008). Similar to the composting process, the ants take on average of two or three months to discard the plant material that is no longer used in the bioreactor. This has been confirmed using $\mathrm{N}:{ }^{15} \mathrm{~N}$ isotope ratios in the leaves collected from A. colombica (Sternberg et al., 2007). However, there are reports showing that the degraded plant material not used for the fungal garden takes four to six weeks to be removed (Aylward et al., 2013).

As in the fungal garden bioreactor, the composting process is the controlled aerobic decomposition of organic wastes through the involvement of mesophilic and thermophilic organisms, which generate a waste residue that can be used as an organic amendment (Körner et al., 2003). However, unlike the well-characterized microorganisms in compost, the contribution of many of the microorganisms that break down plant biomass in the fungal garden bioreactor is not clear, except for the basidiomycete Leucoagaricus gongylophorus (Pagnocca et al., 2001; Silva-Pinhati et al., 2004). The working hypothesis is that the plant material collected by the foraging ants is composted and initially attacked by the arsenal of enzymes of the fungus Leucoagaricus gongylophorus, which confers the capacity to release nutrients that satisfy the demands of a plant. The objective of this work was to determine the effect of Atta mexicana ant waste on the growth of tomato plants and on the soil characteristics under greenhouse conditions.

\section{Materials and methods}

\section{Collection and physical and chemical characterization of ant compost}

Leafcutter ant compost (LCAC) from Atta mexicana was collected in May 2017 in the vicinity of their nests $\left(20^{\circ} 22^{\prime} 54.9^{\prime \prime} \mathrm{N}, 100^{\circ} 04^{\prime} 46.7^{\prime \prime} \mathrm{W}\right)$ and then held in plastic bags until use (Fig. 1A). An LCAC sample was analysed to make the following determinations: total nitrogen $(\mathrm{N})$ was measured using the Dumas method; and potassium $\left(\mathrm{K}_{2} \mathrm{O}\right)$, calcium $(\mathrm{Ca})$, magnesium $(\mathrm{Mg})$, sodium $(\mathrm{Na})$, iron $(\mathrm{Fe})$, copper $(\mathrm{Cu})$, manganese $(\mathrm{Mn})$, phosphorus $\left(\mathrm{P}_{2} \mathrm{O}_{5}\right)$, boron $(\mathrm{B})$ and zinc $(\mathrm{Zn})$ were analysed by spectrometry (Model ICP-iCAP 7000; Thermo Scientific, Massachusetts, USA) following wet digestion (Model Mars 6; CEM, North Carolina, USA) of the material. 
Sulfur (S) was determined by wet digestion (Model Mars 6; CEM, North Carolina, USA) with the turbidimetric method. The electrical conductivity (EC) and $\mathrm{pH}$ were determined following the Mexican Standard NMX-FF-109-SCFI-2007 using a pH meter (Model; PC18, Conductronic, Puebla, Mexico). The moisture content was evaluated using the gravimetric method. The ash and organic content were measured after calcination. The organic carbon content was calculated as a percentage of the original material, whereas the $\mathrm{C} / \mathrm{N}$ ratio was determined on a dry weight basis.
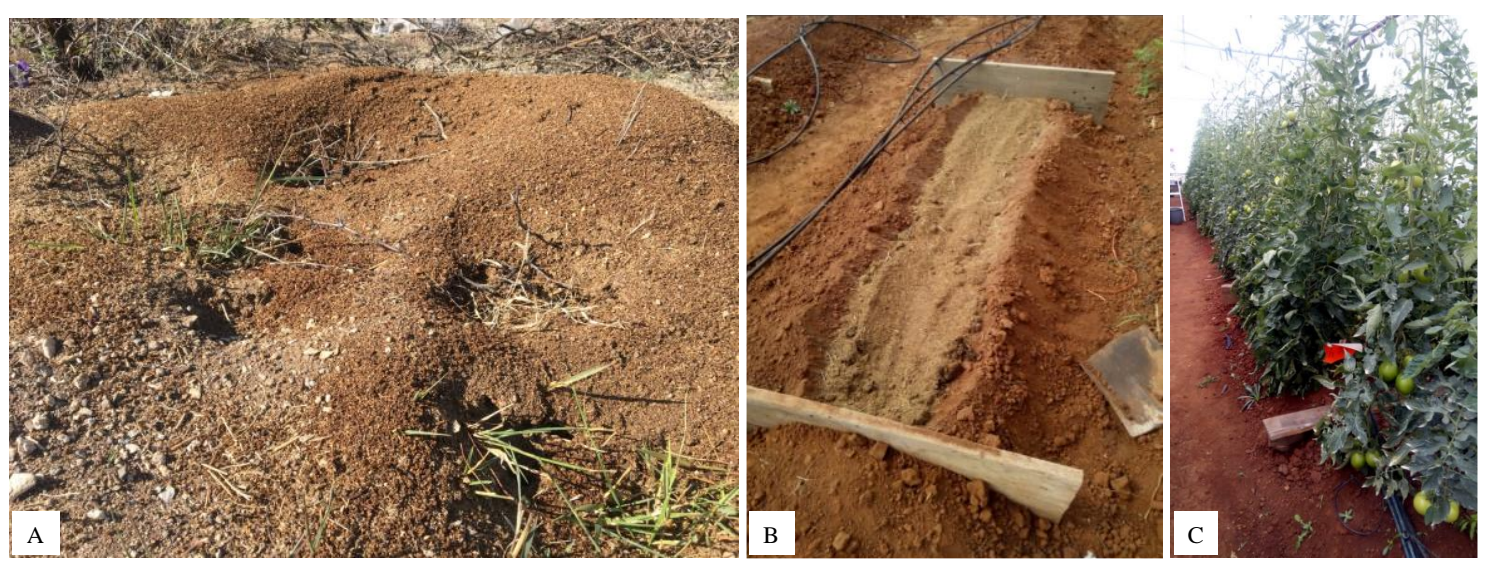

Figure 1. Ant compost (LCAC) application. A) Leaf-cutting ants and their refuse deposits, B) $L C A C$ application at different doses, $C$ ) plants growing in the greenhouse

\section{Plant material, cultivation conditions and treatments}

The experiment was conducted in a greenhouse with lateral and zenithal ventilation at temperatures of 15 to $27{ }^{\circ} \mathrm{C}$, a relative humidity of 45 to $90 \%$ and a maximum of $933 \mathrm{~W} \mathrm{~m}^{-2}$. The study was carried out in Queretaro, Mexico (20³5'28' $\mathrm{N}$, $\left.100^{\circ} 24^{\prime} 36^{\prime \prime} \mathrm{W}\right)$. The LCAC was mixed homogeneously into the soil at a working depth of $30 \mathrm{~cm}$ (Fig. 1B). The dose used was calculated based on the nitrogen content contained in the LCAC and the $\mathrm{N}$ requirement of a tomato plant. Thus, for the first treatment, $15.04 \mathrm{~g}$ of $\mathrm{N}$ per plant was added, which is equivalent to $0.792 \mathrm{~kg}$ of LCAC (Tlow); for the second treatment, $24.70 \mathrm{~g}$ of $\mathrm{N}$ was mixed per plant, which is equivalent to $1.3 \mathrm{~kg}$ of LCAC (Tmed); and for the third treatment, $34.96 \mathrm{~g}$ of $\mathrm{N}$ (1.84 $\mathrm{kg}$ of LCAC) was added per plant (Thigh). A fourth treatment without LCAC was used as a control, but a universal nutrient solution (Steiner, 1984) was used to nourish the plants (Tcontrol). The universal solution contained the following components $\left(\mathrm{mg} \mathrm{L}^{-1}\right)$ : $\mathrm{N}$ (167), P (31), K (277), Mg (49), Ca (183), S (111), Fe (1.33), Mn (0.62), B (0.44), Cu (0.02), $\mathrm{Zn}(0.11)$ and Mo (0.048). The $\mathrm{pH}$ was adjusted to 5.8 using a $\mathrm{pH}$ meter (Model; PC18, Conductronic, Puebla, Mexico). The EC was managed according to the phenological stage of the crop using the method of Ávila-Juárez et al. (2015) using a conductivity meter (Model; PC18, Conductronic, Puebla, Mexico). Tomato seeds (Solanum lycopersicum L. cv. Cid) from Harris Moran were planted in polystyrene germination trays with 200 cavities with peat moss and placed in a germination chamber $\left(80 \% \mathrm{RH}, 25^{\circ} \mathrm{C}\right)$ until germination. After the plants sprouted, they were transplanted to a density of 2.5 plants $\mathrm{m}^{-2}$ in soil with the characteristics listed in Table 2 ("soil before"). The amount of water supplied to the plants was activated by a tensiometer at 
20 centibars placed in each treatment. The experimental design was completely randomized with four treatments, six replicates and an experimental unit of three plants.

\section{Determinations in plants and soil}

Plant growth (16 plants per treatment: Fig. 1C) was measured at 25 (flowering phase), 57, 95 (fruiting phase) and 123 (senescence phase) days after transplant (DAT). The total yield was also measured. Once the experiment was completed, the degree of soil compaction (in $\mathrm{kPa}$ ) at $0.08,0.15$ and $0.30 \mathrm{~m}$ was determined with a soil penetrometer (Spectrum Inc., USA). Samples were taken from 0 to $0.30 \mathrm{~m}$ in depth to determine the following physical properties: saturation (SAT), field capacity (FC), wilting point (WP), hydraulic conductivity (HC), bulk density (BD), cation exchange capacity (CEC) and EC (Model; PC18, Conductronic, Puebla, Mexico). In addition, the following chemical properties were determined: organic matter $(\mathrm{OM})$, inorganic nitrogen (IN), total $\mathrm{P}, \mathrm{K}, \mathrm{Ca}, \mathrm{Mg}, \mathrm{Na}, \mathrm{Fe}, \mathrm{Zn}, \mathrm{Mn}, \mathrm{Cu}, \mathrm{B}, \mathrm{S}$ and $\mathrm{pH}$. The IN was measured using the Dumas method. The EC and $\mathrm{pH}$ values (Model; PC18, Conductronic, Puebla, Mexico) were determined following the Mexican Standard NMX-FF-109-SCFI-2007. The resulting elements $\mathrm{K}, \mathrm{Ca}, \mathrm{Mg}, \mathrm{Na}, \mathrm{Fe}, \mathrm{Cu}, \mathrm{Mn}, \mathrm{P}, \mathrm{B}$ and $\mathrm{Zn}$ were analysed by spectrometry (Model ICP-iCAP 7000; Thermo Scientific, Massachusetts, USA) after wet digestion (Model Mars 6; CEM, North Carolina, USA) of the material.

\section{Quantification of total phenols and flavonoids in tomato fruit}

The tomato samples (16 fruits from 16 plants per treatment) were homogenized with a dispersing instrument (Ultra Turrax) for $1 \mathrm{~min}$ and protected from light with aluminium foil. The homogenized sample $(100 \mathrm{mg})$ was extracted with $2 \mathrm{ml}$ of a methanol:water:formic acid 80:18:2 v/v solution, and the solution was then vortexed for $30 \mathrm{~s}$. The sample was sonicated for $30 \mathrm{~s}$ before being centrifuged at $14,000 \mathrm{rpm}$ for $15 \mathrm{~min}$ at $4{ }^{\circ} \mathrm{C}$. The supernatant was recovered and filtered with a $0.20 \mu \mathrm{m}$ filter and held in the dark at $-20{ }^{\circ} \mathrm{C}$ until analysis. The phenols were extracted using the FolinCiocalteu colorimetric method according to Dewanto et al. (2002). Briefly, the tomato extracts $(30 \mu \mathrm{L})$ were diluted with $460 \mu \mathrm{L}$ of distilled water. Then, $150 \mu \mathrm{L}$ of FolinCiocalteu solution was added to each sample. Subsequently, samples were mixed and allowed to stand for 10 min before adding $120 \mu \mathrm{L}$ of a $20 \%$ sodium carbonate aqueous solution. Afterwards, the samples were left to stand for $120 \mathrm{~min}$ in complete darkness at room temperature. The samples were read at $765 \mathrm{~nm}$ against a blank using a MULTISKAN GO microplate spectrophotometer (Model 51119300; Thermo Scientific, Vantaa, Finland) and compared with the standard. A standard with a known concentration of gallic acid was used for calibration of the curve $(0.0-600 \mu \mathrm{L})$. All values were expressed as the average of three replicates in milligrams of gallic acid equivalents (GAE) per gram of tomato (fresh weight).

The method for the determination of the flavonoid content was modified from Oomah et al. (2005) for use with microplates. Briefly, $100 \mu \mathrm{L}$ of the methanolic extract was mixed with $30 \mu \mathrm{L}$ of $5 \% \mathrm{NaNO}_{2}$ at time zero. After $5 \mathrm{~min}, 30 \mu \mathrm{L}$ of $10 \% \mathrm{AlCl}_{3}$ was added. At $6 \mathrm{~min}, 200 \mu \mathrm{L}$ of $1 \mathrm{~N} \mathrm{NaOH}$ was added. Subsequently, timing was stopped, and $240 \mu \mathrm{L}$ of distilled water was added to each sample and stirred gently until the solutions were homogenized. The samples were read at $510 \mathrm{~nm}$ against a blank using a MULTISKAN GO microplate spectrophotometer (Model 51119300) and compared 
with the standard. A standard with a known concentration of catechin hydrate was used for calibration of the curve $(0-1000 \mu \mathrm{L})$. All values were expressed as the mean of three replicates in milligrams of catechin hydrate $(\mathrm{CH})$ equivalents per gram of tomato (fresh weight).

\section{Determination of antioxidant activity in tomato fruit}

The radical elimination capacity (antioxidant activity) for tomato extract was determined by the 2,2-diphenyl-1-picrylhydrazyl (DPPH) method modified from Oomah et al. (2005) for use in microplates. Briefly, a solution of 2,2-diphenyl-1picrylhydrazyl (DPPH) $(150 \mu \mathrm{M})$ was prepared in $80 \%$ aqueous methanol. The samples or the standard $(20 \mu \mathrm{L})$ were added to a 96-well flat-bottom visible-light plate containing $200 \mu \mathrm{L}$ of the DPPH solution. The plate was covered and left in the dark at room temperature. After $120 \mathrm{~min}$, the absorbance was measured at $480 \mathrm{~nm}$ in a MULTISKAN GO microplate spectrophotometer (Model 51119300) at 30, 60, 90 and $120 \mathrm{~min}$. For each sample or standard, a solution $(20 \mu \mathrm{L})$ of $100 \mu \mathrm{M}$ butyl hydroxytoluene (BHT) was added to each well of the plate containing $200 \mu \mathrm{L}$ of the DPPH solution. Subsequently, the Trolox (6-hydroxy-[2,5,7,8]-tetramethylchroman-[2]carboxylic acid) water-soluble analogue was used to prepare the standard curve (range 0-200 $\mu \mathrm{L}$ ). The activity was reported in milligrams of Trolox equivalent antioxidant capacity (TEAC) per gram of tomato sample. To determine the antioxidant capacity of Trolox by the FRAP method (ferric reducing antioxidant power assay), the tomato extract was prepared in the same manner as for the DPPH method. Then, $20 \mu \mathrm{L}$ of the sample (in triplicate) were mixed with $280 \mu \mathrm{L}$ of the FRAP reagent that was previously prepared with $7.808 \mathrm{mg}$ tripyridyl-s-triazine (TPTZ), $2.5 \mathrm{ml}$ of $40 \mathrm{mM}$ hydrochloric acid, $25 \mathrm{ml}$ of acetate buffer $(1.8 \mathrm{~g}$ of anhydrous sodium acetate, $3.1 \mathrm{~g}$ of sodium acetate trihydrate and $16 \mathrm{ml}$ of glacial acetic acid, adjusted to $1 \mathrm{~L}$ ) and $2.5 \mathrm{ml}$ of $\mathrm{FeCl}_{3}$. The previously made mixture was allowed to rest for $120 \mathrm{~min}$ and was completely protected from light. The samples were then read at $630 \mathrm{~nm}$ against a blank using a MULTISKAN GO microplate spectrophotometer (Model 51119300; Thermo Scientific, Vantaa, Finland) and compared with the standard. A standard with a known concentration of Trolox was used for calibration of the curve $(0-200 \mu \mathrm{L})$. All values are expressed as the mean of three replicates in milligrams of Trolox equivalents (TE) per gram of tomato.

\section{Statistical analysis}

The data were analysed using an analysis of variance (ANOVA). When significant differences were detected, the means were compared using Tukey's test (with $P<0.05$ ) in the Origin Pro 8.0 software (Origin Lab, USA).

\section{Results}

The composition of the LCAC was compared with the previously published composition of three other composts from different production sources, and the results are presented in Table 1. The N content of the LCAC was similar to the published composition of other composts. The K content was $75 \%$ higher in the LCAC compared with conventional compost (composted cow manure) and 6.78 times higher than in municipal waste compost (MWC). The LCAC showed lower values of $\mathrm{Zn}, \mathrm{Cu}$ and $\mathrm{Mn}$ 
than composted cow manure. In general, the nutrient content of the LCAC was as acceptable for supplying crops with nutrients as conventional compost (composted cow manure) and had a $\mathrm{C} / \mathrm{N}$ ratio of 14.4 , which indicates acceptable maturation of the material that ants compost in their nests (Table 1).

Table 1. Comparison between ant compost and compost from different processing sources

\begin{tabular}{c|c|c|c|c}
\hline & LCAC & Cow compost $^{\mathbf{a}}$ & Wood compost $^{\mathbf{b}}$ & MWC compost $^{\mathbf{c}}$ \\
\hline Chemical properties & & & & \\
$\mathrm{pH}$ & 6.34 & 7.26 & 5.19 & 6.9 \\
$\left.\mathrm{EC}(\mathrm{dS} \mathrm{m})^{-1}\right)$ & 6.3 & 3.5 & 5.73 & 12 \\
$\mathrm{~N} \mathrm{total} \mathrm{( \% )}$ & 1.9 & 1.49 & 1.16 & 1.25 \\
$\mathrm{P}\left(\mathrm{P}_{2} \mathrm{O}_{2}\right)(\%)$ & 0.11 & 0.63 & 0.052 & 0.081 \\
$\mathrm{~K}\left(\mathrm{~K}_{2} \mathrm{O}\right)(\%)$ & 1.56 & 0.89 & 0.16 & 0.23 \\
$\mathrm{Ca}(\%)$ & 0.89 & 0.96 & 3.8 & 0.06 \\
$\mathrm{Mg}(\%)$ & 0.22 & 0.3 & 3.33 & 0.03 \\
$\mathrm{Na}(\%)$ & 0.95 & 0.62 & - & 0.12 \\
$\mathrm{~S}(\%)$ & 0.22 & 0.34 & - & 0.09 \\
$\mathrm{Fe}(\%)$ & 0.92 & 0.85 & 0.05 & 0.41 \\
$\mathrm{Cu}(\mathrm{ppm})$ & 17.6 & 41.3 & 0.82 & 230 \\
$\mathrm{Mn}(\mathrm{ppm})$ & 533 & 855 & 14.59 & 240 \\
$\mathrm{Zn}(\mathrm{ppm})$ & 57.2 & 334 & 10.38 & 349 \\
$\mathrm{~B}(\mathrm{ppm})$ & 22.9 & 18.8 & - & - \\
$\mathrm{OM}(\%)$ & 47.3 & 51.3 & - & 18.9 \\
Organic C (\%) & 27.4 & 29.8 & 33.54 & - \\
$\mathrm{Ratio} \mathrm{C/N}$ & 14.4 & 20 & - & 15 \\
\hline
\end{tabular}

LCAC: leafcutter ant compost, MWC: municipal waste compost

aÁvila-Juárez et al. (2015)

${ }^{\mathrm{b}}$ Mladenov (2018)

${ }^{\mathrm{c}}$ Rajaie and Tavakoly (2016)

As can be seen in Table 2, the physical properties of the soil improved as the dose of LCAC increased. The OM of the soil at any dose of LCAC was statistically higher than the OM content of the initial soil and the control, reaching 4.1 times more OM in the soil with respect to the control at the highest dose of LCAC per plant (Fig. 2), which helped to improve the HC; at this high dose of LCAC, the HC was suitable for the soil $\left(0.8 \mathrm{~cm} \mathrm{~h}^{-1}\right)$. The tomato plants showed no deficiencies at any phenological stage, which indicates that the release of the nutrients contained in the LCAC was rapid and timely, even leaving residual acceptable levels in the soil (Table 2). In contrast, at the end of the experiment, the application of chemical fertilizers left unused ions that can be leached or accumulate over time and be harmful to the subsequent crop. For example, the control treatment left 2.8 times more $\mathrm{NO}_{3}{ }^{-}$and 4.84 times more $\mathrm{S}$ in the soil compared with the high dose of LCAC (Table 2). These ions are noted here because the soil cannot retain them given their negative charge, which easily leads to leaching and contamination of groundwater. 
Table 2. Physicochemical properties of the soil before and after adding ant compost to a tomato crop (in $\mathrm{kg}$ of LCAC per plant: Tlow $=0.792$; Tmed $=1.3$; Thigh $=1.84$ )

\begin{tabular}{|c|c|c|c|c|c|}
\hline & \multirow{2}{*}{ Soil before } & \multicolumn{4}{|c|}{ Soil after } \\
\hline & & $\mathbf{T}_{\text {low }}$ & $\mathbf{T}_{\text {med }}$ & $\mathbf{T}_{\text {high }}$ & $\mathbf{T}_{\text {control }}$ \\
\hline \multicolumn{6}{|l|}{ Physical properties } \\
\hline SAT $(\%)$ & 54.0 & 53.1 & 57.5 & 63.3 & 53.8 \\
\hline $\mathrm{FC}(\%)$ & 28.9 & 28.3 & 30.8 & 33.9 & 28.8 \\
\hline $\mathrm{WP}(\%)$ & 17.2 & 16.8 & 18.3 & 20.2 & 17.1 \\
\hline $\mathrm{HC}\left(\mathrm{cm} \mathrm{h}^{-1}\right)$ & 4.1 & 2.3 & 1.6 & 0.8 & 2.3 \\
\hline $\mathrm{BD}\left(\mathrm{g} \mathrm{cm}^{-3}\right)$ & 1.0 & 0.9 & 0.8 & 0.8 & 0.9 \\
\hline $\mathrm{EC}\left(\mathrm{dS} \mathrm{m} \mathrm{m}^{-1}\right)$ & 0.1 & 0.4 & 1.1 & 1.1 & 1.4 \\
\hline $\mathrm{CEC}\left(\right.$ meq $\left.100 \mathrm{~g}^{-1}\right)$ & 11.1 & 10.3 & 13.1 & 13.8 & 9.6 \\
\hline \multicolumn{6}{|l|}{ Chemical properties } \\
\hline $\mathrm{pH}(1: 2$ water $)$ & 6.7 & 6.0 & 6.3 & 6.2 & 5.8 \\
\hline IN (ppm) & 3.5 & 21.0 & 33.7 & 37.2 & 106.7 \\
\hline P-Bray (ppm) & 0.6 & 42.1 & 51.3 & 58.0 & 34.4 \\
\hline $\mathrm{K}(\mathrm{ppm})$ & 173.0 & 290.0 & 605.3 & 638.3 & 385.0 \\
\hline $\mathrm{Ca}(\mathrm{ppm})$ & 1557.0 & 1331.0 & 1604.0 & 1700.7 & 1184.0 \\
\hline $\mathrm{Mg}(\mathrm{ppm})$ & 340.0 & 326.0 & 402.7 & 418.3 & 309.7 \\
\hline $\mathrm{Na}(\mathrm{ppm})$ & 15.0 & 40.2 & 46.4 & 49.7 & 42.5 \\
\hline $\mathrm{Fe}(\mathrm{ppm})$ & 7.3 & 5.2 & 7.5 & 9.6 & 4.8 \\
\hline $\mathrm{Zn}(\mathrm{ppm})$ & 0.3 & 0.8 & 2.0 & 1.6 & 0.9 \\
\hline $\mathrm{Mn}(\mathrm{ppm})$ & 20.8 & 18.6 & 32.7 & 44.0 & 7.2 \\
\hline $\mathrm{Cu}(\mathrm{ppm})$ & 0.2 & 0.3 & 0.4 & 0.5 & 0.2 \\
\hline $\mathrm{B}(\mathrm{ppm})$ & 0.1 & 0.3 & 0.3 & 0.4 & 0.4 \\
\hline $\mathrm{S}(\mathrm{ppm})$ & 6.1 & 12.6 & 20.8 & 21.3 & 103.2 \\
\hline
\end{tabular}
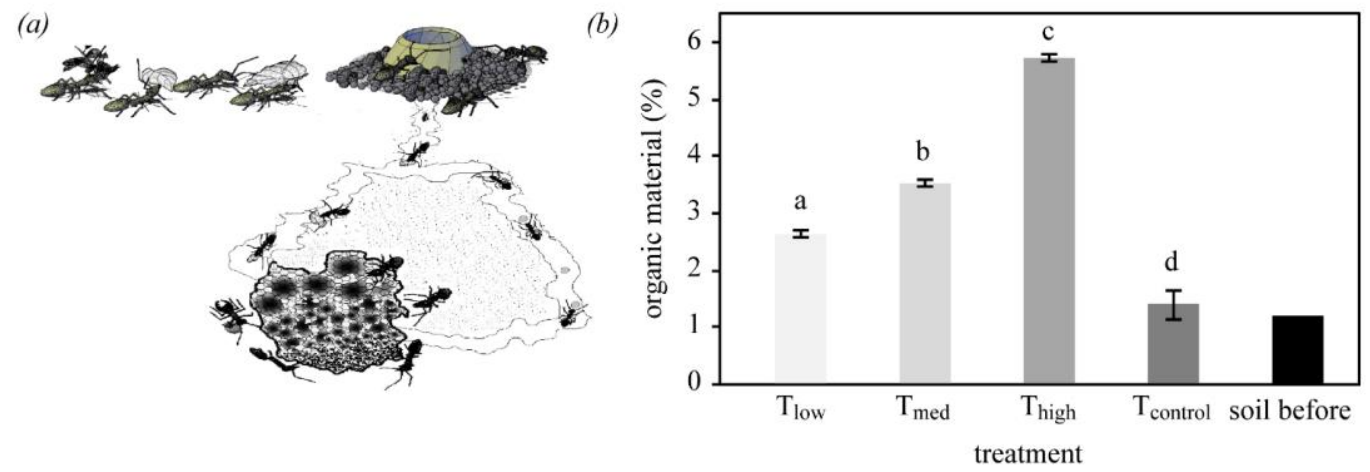

Figure 2. Ant compost increases the OM content of the soil. (a) Production of ant compost by Atta mexicana. (b) Increase in OM in the soil by the application of ant compost. Doses of LCAC in $\mathrm{kg}$ per plant: Tlow $=0.792 ;$ Tmed $=1.3$; Thigh $=1.84$. Mean \pm standard error, $p<0.001$ with Tukey's test

In general, in all treatments where the LCAC was applied, the compaction was well below the level considered moderate (more than $200 \mathrm{kPa}$ ). In fact, on average, these treatments showed $18 \%$ less soil compaction than the initial soil. In the control treatment, 
conditions similar to the initial soil were observed with only a $1.8 \%$ increase in compaction (Fig. 3). The treatment that reduced compaction to the greatest degree was the dose administered at $0.792 \mathrm{~kg}$ of LCAC per plant, which is equivalent to $19.8 \mathrm{t} \mathrm{ha}^{-1}$.

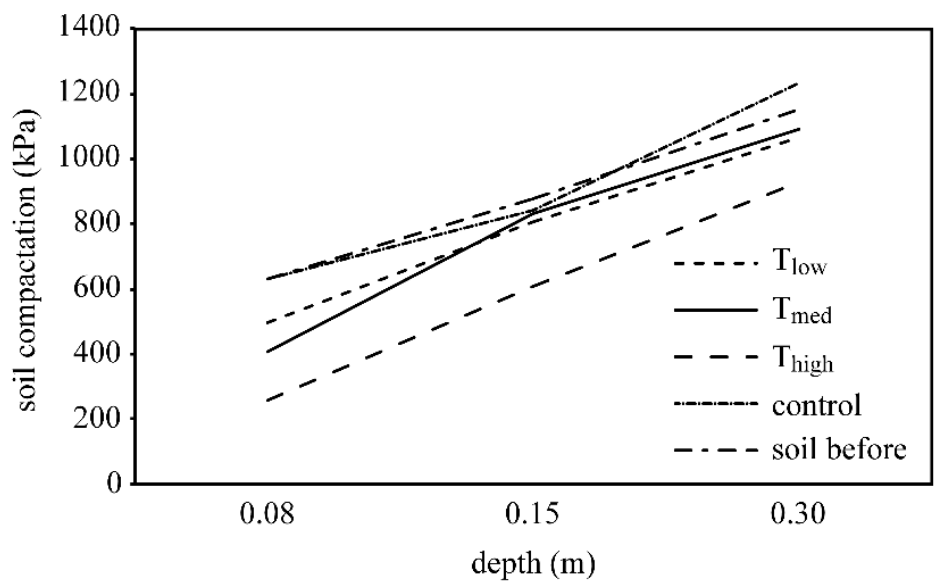

Figure 3. Soil compaction at different depths as a result of ant compost before and after the experiment (doses of LCAC in kg per plant: Tlow $=0.792 ;$ Tmed $=1.3$; Thigh $=1.84$ )

In general, plant height was similar in the treatments with the medium $(1.3 \mathrm{~kg})$ and high dose $(1.84 \mathrm{~kg})$ of LCAC with respect to the control. There was only one taller plant at 57 DAT for the aforementioned treatments compared with the control (Fig. 4). The total daily growth in the high LCAC treatment was $2.24 \mathrm{~cm}$, which was not statistically different from the control. We only found differences in plant height between the Tlow and Thigh treatments, which have the lowest and highest doses of LCAC, respectively, and therefore the lowest and highest nutrient contents. This finding may suggest that high doses of LCAC provided sufficient levels of nutrients such as NPK that are necessary to form plant biomass.

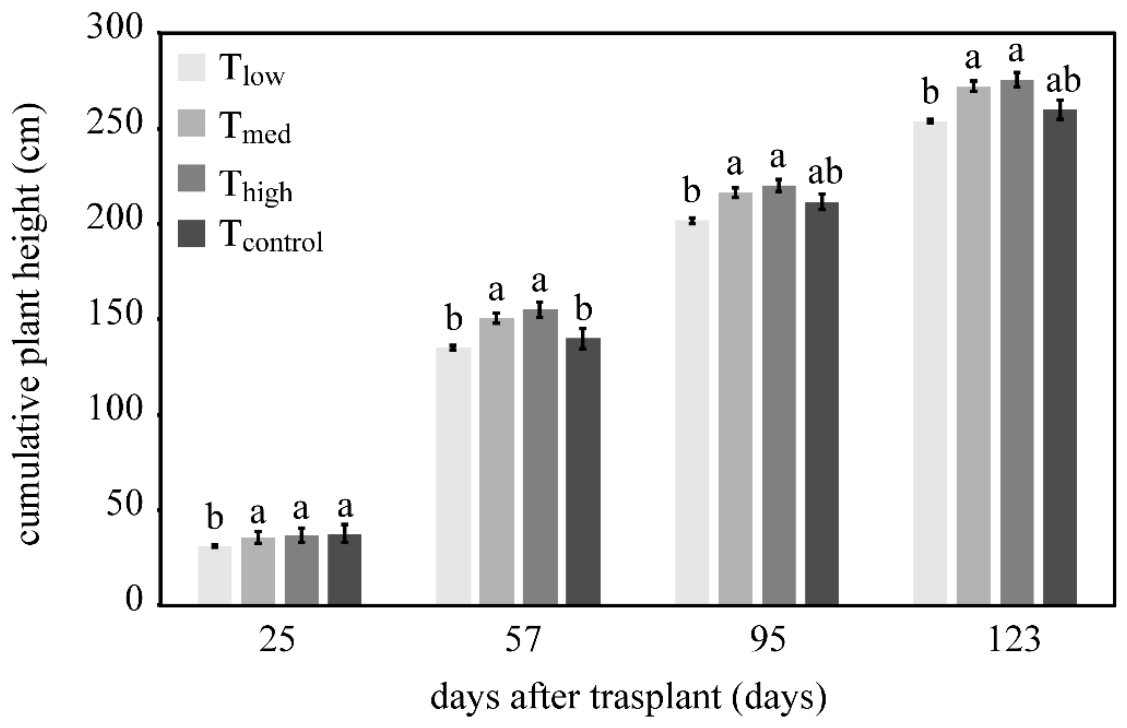

Figure 4. Effect of the application of ant compost on plant height at different days after transplant. Doses of LCAC in kg per plant: Tlow $=0.792 ;$ Tmed $=1.3 ;$ Thigh $=1.84$.

Mean \pm standard error, $p<0.05$ with Tukey's test 
According to our results, the application of LCAC at $19.8 \mathrm{t} \mathrm{ha}^{-1}$ (Tlow) or $46 \mathrm{t} \mathrm{ha}^{-1}$ (Thigh) at a density of 2.5 plants $\mathrm{m}^{-2}$ in a greenhouse tomato crop produced the same yield ( $p<0.05)$ as the application of chemical fertilizers. This finding indicates that ant compost has a high nutrient content that is readily available to the plant (the LCAC was applied one week before transplanting) (Fig. 5). For example, the high dose of LCAC provided $19 \mathrm{~kg}$ of $\mathrm{N}$ for each ton applied, which is higher than composted cow manure that provided $35 \mathrm{~g}$ of $\mathrm{N}$ per plant, whereas chemical fertilization provided $20.54 \mathrm{~g}$ of $\mathrm{N}$ per plant (167 $\mathrm{ppm} \mathrm{NL}^{-1}$ for 153 days).

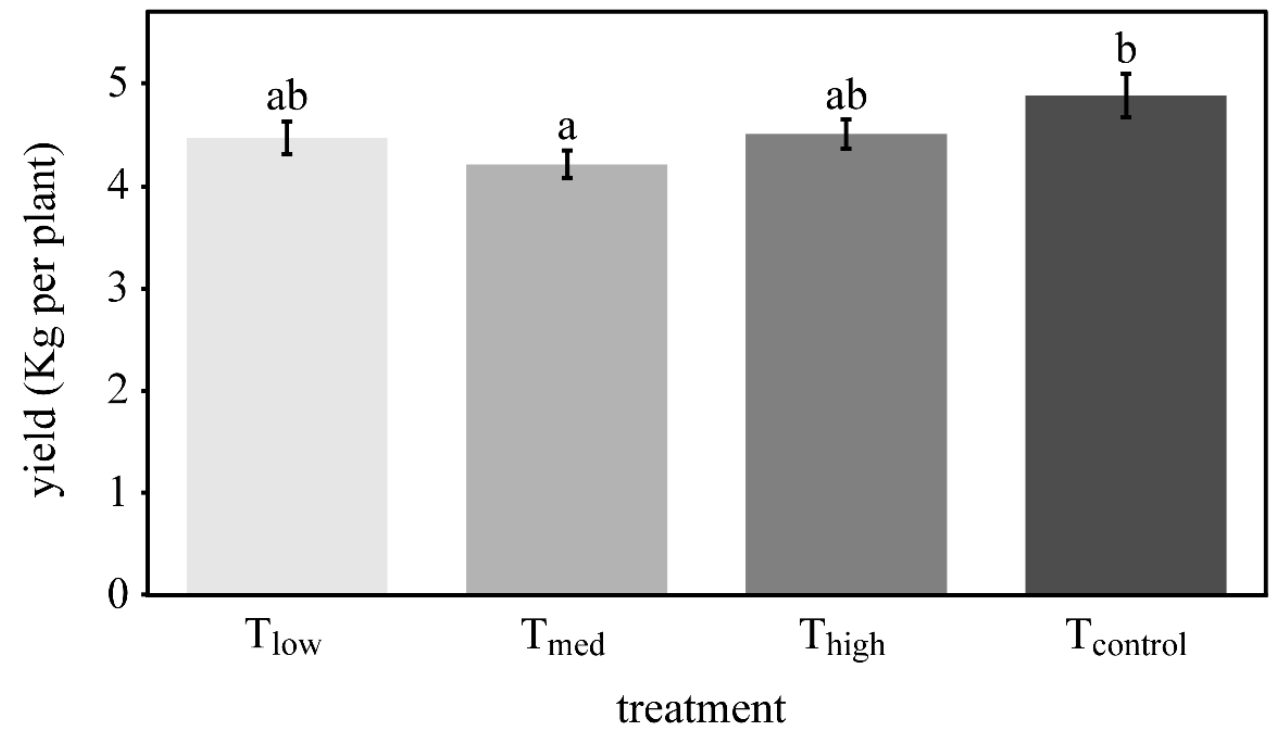

Figure 5. Tomato plant yield for different applications of ant compost. Doses of LCAC in kg per plant: Tlow $=0.792 ;$ Tmed $=1.3 ;$ Thigh $=1.84$. Mean \pm standard error, $p<0.05$ with Tukey's test

There were no significant differences $(\mathrm{p}<0.05)$ in the content of total phenols, flavonoids or antioxidant capacity in the LCAC treatments compared with the control. The level of nutrients in the LCAC was sufficient, in terms of quantity and availability, to avoid biochemical damage to the plant that could lead to a loss of nutraceutical properties (Fig. 6).

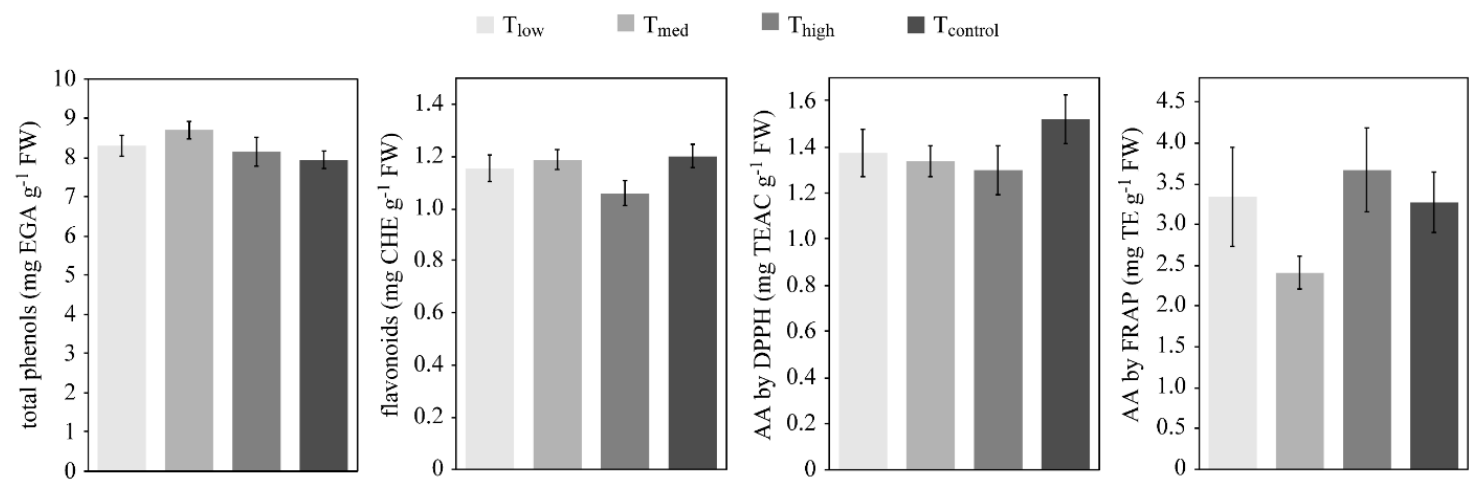

Figure 6. Effect of different doses of ant compost on the biochemical properties of tomato fruit. Doses of LCAC in kg per plant: Tlow $=0.792 ;$ Tmed $=1.3 ;$ Thigh $=1.84$. Mean and standard error ( $n=18$ or more), $p<0.05$ with Tukey's test 


\section{Discussion}

The cell wall of plants is composed of cellulose, hemicellulose and pectin, which represents $70 \%$ of plant biomass (Jørgensen et al., 2007), as well as macro and microelements (Bolan et al., 2010) and some trace elements (Faridullah et al., 2014). The fungus $L$. gongylophorus has developed the ability to produce lignocellulases, pectinases, amylases and cellulases that disintegrate plant matter (Aylward et al., 2013) into more soluble compounds (Huang et al., 2014), simultaneously lysing the cell by the penetration of their hyphae and releasing the nutritional content of the leaves, including $\mathrm{N}, \mathrm{P}, \mathrm{K}$ and $\mathrm{Ca}$. This finding suggests that the LCAC contains the necessary nutrients to meet the nutritional demands of a tomato plant. In terms of yield, the treatments with LCAC at low and high doses were not significantly different from the control treatment (with soluble fertilizers). Given the need to take advantage of agricultural waste, various treatment techniques have been developed such as vermicomposting, anaerobic digestion and various composting strategies (Altuntas et al., 2018; Irshad et al., 2013; Nayak and Kalamdhad, 2014; Yardimci, 2013). In the case of LCAC, composting is performed as part of the symbiotic relationship between the ants of the genus Atta, among other genera, and the fungus L. gongylophorus. Although it is not clear when this symbiotic relationship developed, we are certain that it was hundreds of years ago. The production of the ant waste we refer to as "ant compost" is very similar to a solid state reactor because the fungal garden produces not only biomass as a raw material but also a series of microbial secretions, enzymes and hydrolysis products; the ants prepare the plant substrate to feed the system, and the cellular mass is continuously reinoculated, naturally producing waste material (ant compost) (Somera et al., 2015). One of the sterilization phases in the composting process is the thermophilic phase, in which a large quantity and variety of microorganisms that can damage the plant die. However, in this high-temperature phase (above $40{ }^{\circ} \mathrm{C}$ ) (Chen et al., 2011), it is common for some of the nitrogen to volatilize in the form of ammonia, particularly when the $\mathrm{pH}$ is close to 7 (Tam and Tiquia, 1999). In the LCAC, the $\mathrm{pH}$ was 6.34. The higher $\mathrm{N}$ content ( $27 \%$ more than composted cow manure) may explain the good $\mathrm{pH}$ regulation maintained by the ants in their nests (by an as yet unknown process). The ratio of $\mathrm{C} / \mathrm{N}$ at the end of the composting process is one of the most frequently measured indicators of stability. In general, the $\mathrm{C} / \mathrm{N}$ ratio decreases as the compost matures due to the loss of carbon in the form of carbon dioxide (Raj and Antil, 2011; Wichuk and McCartney, 2010). A C/N ratio below 20 is adequate for a mature compost; however, a C/N ratio lower than 15 is more desirable (Raj and Antil, 2011). The LCAC had a $\mathrm{C} / \mathrm{N}$ ratio of 14.4 before being applied, whereas composted cow manure has a ratio of approximately 20 (Ávila-Juárez et al., 2015). The low $\mathrm{C} / \mathrm{N}$ ratio of ant compost, together with the decrease in OM, explains the higher degree of maturity in the LCAC because when the OM is lost, the dry weight is reduced and the proportion of $\mathrm{C} / \mathrm{N}$ decreases (Bernal et al., 2009). Although the $\mathrm{C} / \mathrm{N}$ of any compost depends on the input used, in the case of the ants, this ratio depends fundamentally on the type of forage harvested by the ants (Huang et al., 2014). The levels of $\mathrm{N}$ and $\mathrm{C}$ in the LCAC suggest that there is little loss of these two elements, possibly because the composting process occurs in partially closed underground chambers. EC has been proposed as an indicator of compost stability, and its lower limit should be $3 \mathrm{mS} \mathrm{m}^{-1}$ (Gao et al., 2010) with a maximum of $4 \mathrm{mS} \mathrm{m}^{-1}$ (Chowdhury et al., 2013). The EC of ant compost was $6.3 \mathrm{mS} \mathrm{m}^{-}$ ${ }^{1}$, which is $80 \%$ higher than composted cow manure and $52.5 \%$ less than the MWC. Because EC is the content of soluble salts in the compost (Gao et al., 2010), the ant 
compost had a higher content of available nutrients for the plant compared with composted cow manure, which is reflected in the similarity of yields found in the treatments with medium and high doses and compared with the control, in which soluble chemical fertilization was applied. We believe that the limits of EC that have been established to indicate whether a compost is mature and stable should be a function of the quality and quantity of its components (nutrients) and not the EC of the compost because there are elements such as $\mathrm{Na}$ that elevate the $\mathrm{EC}$ without being essential or beneficial for the plant. In fact, the fewer trace elements or $\mathrm{Na}$ that a compost contains and the higher the proportions of essential elements, the greater the EC of a compost, which translates into less application to the soil needed to meet nutritional demands.

Compost has been used for many years as a fertilizer due to its ability to increase soil health (Arslan et al., 2008; Canali et al., 2011); promote the increase in aggregates, structure and fertility of the soil; increase the population of beneficial microorganisms; and increase the water-holding capacity and cation exchange (Angelova et al., 2013; Arslan et al., 2008). The HC serves as an indicator of the movement of water and solutes in the soil. If the $\mathrm{HC}$ is below $0.5 \mathrm{~cm} \mathrm{~h}^{-1}$, drainage can be compromised causing possible root problems (Saunders et al., 1978). However, there are problems with water retention and the loss of nutrients to the subsoil. The $\mathrm{HC}$ was decreased in treatments with compost, up to $0.8 \mathrm{~cm} \mathrm{~h}^{-1}$ for the high dose, as has been found with the use of conventional compost (Angelova et al., 2013; Arslan et al., 2008). This finding is mainly because the treatment with the high dose contained four times more OM than the control, which caused an $80 \%$ reduction in the $\mathrm{HC}$ and improved water retention as evidenced by the FC, which had increased by $17.3 \%$ at the end of the experiment. Our results confirm that the $\mathrm{OM}$ in the soil has an impact on the percolation of water through the soil and increases the water-holding capacity (Uzoma et al., 2011). In contrast, the absence of $\mathrm{OM}$ in the soil causes, in addition to salt accumulation, a decrease in SAT as observed in the control and the treatment with a low dose of compost. Similar patterns were observed for FC and the WP, possibly as a result of a very high $\mathrm{HC}\left(2.3 \mathrm{~cm} \mathrm{~h}^{-1}\right)$, which was derived from an absence of OM in the soil.

A common practice among farmers is to add compost one month before transplanting so that the soil microorganisms can help release/solubilize the nutrients present in the compost and make them available for the development of the plant. In the case of the LCAC, it was not necessary to allow a significant period of time before transplanting (it was added one week before), because it possessed a high EC. As mentioned previously, the EC measures the amount of soluble salts present in the sample. It has been observed that when compost is added to the soil, there is a high level of $\mathrm{N}$ in the form of $\mathrm{NH}_{4}{ }^{+}$, and through the process of nitrification, $\mathrm{H}^{+}$ions are released, which causes a decrease in the $\mathrm{pH}$ of the medium (Shen et al., 2011). The $\mathrm{pH}$ of the LCAC was 6.34, and at the end of the experiment, the $\mathrm{pH}$ of the soil was 6 to 6.3 at the different doses used, which was well above the control treatment. It is possible that in the Atta mexicana fungal garden, the nitrification process is operating because the plants in our experiment showed no $\mathrm{N}$ deficiencies or toxicity. The concentration of $\mathrm{P}$ in the LCAC was almost six times lower than that reported for compost (Ávila-Juárez et al., 2015). However, at the end of the experiment, the treatments with LCAC had more P than the control, which indicates that the $\mathrm{P}$ present was sufficient for plant growth and was immediately available because the $\mathrm{P}$ of a compost recently applied to the soil is typically immobilized by soil microorganisms, which leads to low availability to plants (Barral et al., 2011). This 
finding confirms that when the LCAC was applied, there was no need for nutrient transformation from a poorly soluble state to a more soluble state by soil microorganisms, as is the case with conventional composts. However, the high availability of $\mathrm{P}$ for the tomato crop was the result of the adequate $\mathrm{pH}$ of the LCAC, because $\mathrm{pH}$ values below 6 and above 7.5 directly affect the availability of $\mathrm{P}$ (Fuentes et al., 2006). The increase in $\mathrm{Ca}$ in the soil increases with the dose of the compost (Ch'ng et al., 2014), which was reflected in the treatments with LCAC. The highest Ca content in the soil at the end of the experiment was observed in the high-dose LCAC treatment $\left(46 \mathrm{t} \mathrm{ha}^{-1}\right)$. This result can be attributed to the relatively high concentration of $\mathrm{Ca}$ in the compost before being applied to the soil and to the relatively high initial concentration that the soil possessed before the experiment (1557 ppm). The high concentration of $\mathrm{K}$ in the soil, which was also dose-dependent, was a product of the high concentration of $\mathrm{K}$ in the compost $(1.56 \%)$ and its release during the decomposition of the $\mathrm{OM}$ in the "fungal garden". The highest concentration of $\mathrm{K}$ in the soil (638 ppm) was obtained with a dose of $46 \mathrm{t} \mathrm{ha}^{-1}$ of LCAC, which is 1.65 times more than with chemical fertilization, suggesting that there is residual $\mathrm{K}$ available for the next crop and that less LCAC could be used for the next cycle. The increase in $\mathrm{Mg}, \mathrm{Fe}, \mathrm{Zn}, \mathrm{Mn}$ and $\mathrm{Cu}$ in the soil can be attributed to the release of these elements during the decomposition/mineralization of the compost in the "fungal garden". Similar results for the content of $\mathrm{OM}, \mathrm{C}, \mathrm{N}, \mathrm{P}, \mathrm{Ca}, \mathrm{K}$ and $\mathrm{Mg}$ have been reported (Farji-Brener and Ghermandi, 2008). This increase is to be expected because the leaves collected by the ants are important stores of nutrients that plants take up from the soil. These nutrients, derived from the enzymatic processes mentioned above, are released into more soluble forms and concentrated in the nests of the ants and are derived from the reduction in the biomass collected.

For millennia, compost has been used for soil remediation and as an amendment to add nutrients for crops (Indriyati, 2014). Our results show that there was no significant difference in the plant height between the LCAC treatments and the control at the end of the experiment (123 DAT). However, the content of major nutrients such as NPK with an LCAC dose of $19.8 \mathrm{t} \mathrm{ha}^{-1}$ (Tlow) was not sufficient to meet the nutrient demands of the tomato crop because there was a significant difference in yield (410 $\left.\mathrm{g} \mathrm{plant}^{-1}\right)$ with respect to the control. This result was confirmed by the yields of the tomato fruit (fresh weight) from the high and medium dose treatments of LCAC, which were not statistically different from the control. The quantity $(\mathrm{kg})$ of fertilizer supplied by the nutrient solution (Steiner, 1984) during the experiment for the tomato crop were N:770, $\mathrm{P}: 143, \mathrm{~K}: 1278$, whereas for the high LCAC dose $\left(46 \mathrm{t} \mathrm{ha}^{-1}\right)$, they were N:874, P:50.6, $\mathrm{K}: 718$. The $\mathrm{P}$ level in the nutrient solution was 2.8 times higher than the $\mathrm{P}$ level of the high-dose LCAC; however, $\mathrm{P}$ did not limit the yield from tomato cultivation. In contrast, the contribution of $\mathrm{OM}$ from the LCAC may have reduced the $\mathrm{HC}$, resulting in less leaching of nutrients such as $\mathrm{P}$ and $\mathrm{K}$, because after the experiment the residual $\mathrm{P}$ and $\mathrm{K}$ in the soil was higher than in the soil with the nutrient solution. Our results suggest that a) the variety and quantity of nutrients present in the LCAC are sufficient (at Tlow and Thigh) to grow a tomato crop without the need for inorganic fertilizers and b) the nutrients present in the LCAC are highly soluble and can be immediately taken up by the plant once the tomato root has contact with the LCAC. Our results concur with other previously published studies on the growth surrounding Acromyrmex ant nests, which are very similar to those of Atta mexicana, which concluded that the nutrient content of the ant waste is high enough to satisfy the demands of a plant (Farji- 
Brener and Werenkraut, 2017; Farji-Brener and Ghermandi, 2008; Saha et al., 2012). However, we found no significant differences in total phenols, flavonoids or antioxidant activity via DPPH or FRAP in any of the compost treatments compost compared with the control. This finding indicates that the dose of LCAC used does not modify the secondary metabolism of the tomato plant.

\section{Conclusions}

In summary, we discovered that the symbiotic relationship between the ant Atta mexicana and the fungus $L$. gongylophorus produces a product very similar to the conventional composted cow manure produced by humans. Given the nutritional characteristics and other indicators such as the $\mathrm{C} / \mathrm{N}$ ratio found in ant waste, it is inferred that the ants facilitate a process similar to that of the composting activities that have been performed by humans for many years. In fact, the LCAC was able to satisfy the nutritional demands, in terms of quality and quantity of nutrients, of a tomato crop without the need for inorganic fertilizers. The LCAC increased the amount of OM and provided nutrients to the soil as does a conventional compost. Atta spp. are excellent nutrient recyclers and maintain an ecological balance in the environment by producing a high-quality compost that is available to plants. For future research, we recommend analyzing the effect of LCAC on the soil for a longer period of time, such as 3 years, as it may, according to our results, positively modify the soil by supporting the recovery of eroded soils without the use of physical structures or plant-based nutrient contents.

Acknowledgements. The authors acknowledge support from the Autonomous University of Queretaro, Queretaro, Mexico. Additionally, they acknowledge FOVIN-UAQ (SUV-DVT-2018-031) and FOFIUAQ (FIN-2018-24) for partial support of this research.

\section{REFERENCES}

[1] Altuntas, O., Durak, A., Kucuk, R. (2018): Optimization and comparison of the effects of vermicompost and conventional fertilization on spinach (Spinacia oleracea L.) growth. Applied Ecology and Environmental Research 16: 7001-7016.

[2] Angelova, V., Akova, V., Artinova, N., Ivanov, K. (2013): The effect of organic amendments on soil chemical characteristics. - Bulgarian Journal of Agricultural Science 19: 958-971.

[3] Arslan, E., Obek, E., Kirbag, S., Ipek, U., Topal, M. (2008): Determination of the effect of compost on soil microorganisms. - International Journal of Science \& Technology 3: 151-159.

[4] Ávila-Juárez, L., Rodríguez González, A., Rodríguez Piña, N., Guevara González, R. G., Torres Pacheco, I., Ocampo Velázquez, R. V., Moustapha, B. (2015): Vermicompost leachate as a supplement to increase tomato fruit quality. - Journal of Soil Science and Plant Nutrition 15: 46-59.

[5] Aylward, F. O., Burnum-Johnson, K. E., Tringe, S. G., Teiling, C., Tremmel, D. M., Moeller, J. A., Scott, J. J., Barry, K. W., Piehowski, P. D., Nicora, C. D., Malfatti, S. A., Monroe, M. E., Purvine, S. O., Goodwin, L. A., Smith, R. D., Weinstock, G. M., Gerardo, N. M., Suen, G., Lipton, M. S., Currie, C. R. (2013): Leucoagaricus gongylophorus produces diverse enzymes for the degradation of recalcitrant plant polymers in leaf-cutter ant fungus gardens. - Applied and Environmental Microbiology 79(12): 3770-3778. 
[6] Barral, M. T., Paradelo, R., Domínguez, M., Díaz-Fierros, F. (2011): Nutrient release dynamics in soils amended with municipal solid waste compost in laboratory incubations. - Compost Science \& Utilization 19(4): 235-243.

[7] Bernal, M. P., Alburquerque, J. A., Moral, R. (2009): Composting of animal manures and chemical criteria for compost maturity assessment. A review. - Bioresource Technology 100(22): 5444-5453.

[8] Bolan, N. S., Szogi, A. A., Chuasavathi, T., Seshadri, B., Rothrock, M. J., Panneerselvam, P. (2010): Uses and management of poultry litter. - World's Poultry Science Journal 66(4): 673-698.

[9] Bot, A. N. M., Currie, C. R., Hart, A. G., Boomsma, J. J. (2001): Waste management in leaf-cutting ants. - Ethology Ecology \& Evolution 13(3): 225-237.

[10] Canali, S., Di Bartolomeo, E., Tittarelli, F., F., M., Verrastro, V., Ferri, D. (2011): Comparison of different laboratory incubation procedures to evaluate nitrogen mineralization in soils amended with aerobic and anaerobic stabilized organic materials. Journal of Food Agriculture and Environment 9(2): 540-546.

[11] Ch'ng, H. Y., Ahmed, O. H., Majid, N. M. A. (2014): Improving phosphorus availability in an acid soil using organic amendments produced from agroindustrial wastes. - The Scientific World Journal 2014: 506356.

[12] Chen, L., Marti, M. D. H., Moore, A., Falen, C. (2011): The Composting Process. - The University of Idaho, Moscow.

[13] Chowdhury, A. K. M. M. B., Akratos, C. S., Vayenas, D. V., Pavlou, S. (2013): Olive mill waste composting: a review. - International Biodeterioration \& Biodegradation 85: 108-119.

[14] Dewanto, V., Wu, X., Adom, K. K., Liu, R. H. (2002): Thermal processing enhances the nutritional value of tomatoes by increasing total antioxidant activity. - Journal of Agricultural and Food Chemistry 50(10): 3010-3014.

[15] Faridullah, P. A., Irshad, M., Alam, A., Mahmood, Q., Ashraf, M. (2014): Trace elements characterization in fresh and composted livestock manures. - Austin Journal of Hydrology 1: 1-16.

[16] Farji-Brener, A. G., Ghermandi, L. (2008): Leaf-cutting ant nests near roads increase fitness of exotic plant species in natural protected areas. - Proceedings of the Royal Society B: Biological Sciences 275(1641): 1431-1440.

[17] Farji-Brener, A. G., Werenkraut, V. (2017): The effects of ant nests on soil fertility and plant performance: a meta-analysis. - Journal of Animal Ecology 86(4): 866-877.

[18] Fuentes, B., Bolan, N., Naidu, R., Mora, M. D. L. L. (2006): Phosphorus in organic waste-soil systems. - Revista de la Ciencia del Suelo y Nutrición Vegetal 6(2): 64-83.

[19] Gao, M., Liang, F., Yu, A., Li, B., Yang, L. (2010): Evaluation of stability and maturity during forced-aeration composting of chicken manure and sawdust at different $\mathrm{C} / \mathrm{N}$ ratios. - Chemosphere 78(5): 614-619.

[20] Hart, A. G. (2002): Waste management in the leaf-cutting ant Atta colombica. Behavioral Ecology 13(2): 224-231.

[21] Hölldobler, B., Wilson, E. O. (1990): The Ants. - Harvard University Press, Cambridge, MA.

[22] Huang, E. L., Aylward, F. O., Kim, Y.-M., Webb-Robertson, B.-J. M., Nicora, C. D., Hu, Z., Metz, T. O., Lipton, M. S., Smith, R. D., Currie, C. R., Burnum-Johnson, K. E. (2014): The fungus gardens of leaf-cutter ants undergo a distinct physiological transition during biomass degradation. - Environmental Microbiology Reports 6(4): 389-395.

[23] Indriyati, L. T. (2014): Chicken manure composts as nitrogen sources and their effect on the growth and quality of Komatsuna (Brassica rapa L.). - Journal of the International Society for Southeast Asian Agricultural Sciences 20(1): 52-63.

[24] Irshad, M., Eneji, A. E., Hussain, Z., Ashraf, M. (2013): Chemical characterization of fresh and composted livestock manures. - Journal of Soil Science and Plant Nutrition 13: 115-121. 
[25] Jørgensen, H., Vibe-Pedersen, J., Larsen, J., Felby, C. (2007): Liquefaction of lignocellulose at high-solids concentrations. - Biotechnology and Bioengineering 96(5): 862-870.

[26] Körner, I., Braukmeier, J., Herrenklage, J., Leikam, K., Ritzkowski, M., Schlegelmilch, M., Stegmann, R. (2003): Investigation and optimization of composting processes - test systems and practical examples. - Waste Management 23(1): 17-26.

[27] Little, A. E. F., Murakami, T., Mueller, U. G., Currie, C. R. (2006): Defending against parasites: fungus-growing ants combine specialized behaviours and microbial symbionts to protect their fungus gardens. - Biology Letters 2(1): 12-16.

[28] Mladenov, M. (2018): Chemical composition of different types of compost. - Journal of Chemical Technology and Metallurgy 53: 712-716.

[29] Moller, I. E., De Fine Licht, H. H., Harholt, J., Willats, W. G. T., Boomsma, J. J. (2011): The dynamics of plant cell-wall polysaccharide decomposition in leaf-cutting ant fungus gardens. - PLoS ONE 6(3): e17506.

[30] Moutinho, P., Nepstad, D. C., Davidson, E. A. (2003): Influence of leaf-cutting ant nests on secondary forest growth and soil properties in Amazonia. - Ecology 84(5): 1265-1276.

[31] Mueller, U. G., Schultz, T. R., Currie, C. R., Malloch, D. (2001): The origin of the attine ant-fungus mutualism. - The Quarterly Review of Biology 76(2): 169-197.

[32] Mueller, U. G., Gerardo, N. M., Aanen, D. K., Six, D. L., Schultz, T. R. (2005): The evolution of agriculture in insects. - Annual Review of Ecology, Evolution, and Systematics 36(1): 563-595.

[33] Nayak, A. K., Kalamdhad, A. S. (2014): Feasibility of composting combinations of sewage sludge, cattle manure, and sawdust in a rotary drum reactor. - Environmental Engineering Research 19(1): 47-57.

[34] Oomah, B. D., Cardador-Martínez, A., Loarca-Piña, G. (2005): Phenolics and antioxidative activities in common beans (Phaseolus vulgaris L). - Journal of the Science of Food and Agriculture 85(6): 935-942.

[35] Pagnocca, F. C., Bacci, M., Fungaro, M. H., Bueno, O. C., Hebling, M. J., Sant'anna, A., Capelari, M. (2001): RAPD analysis of the sexual state and sterile mycelium of the fungus cultivated by the leaf-cutting ant Acromyrmex hispidus fallax. - Mycological Research 105(2): 173-176.

[36] Raj, D., Antil, R. S. (2011): Evaluation of maturity and stability parameters of composts prepared from agro-industrial wastes. - Bioresource Technology 102(3): 2868-2873.

[37] Rajaie, M., Tavakoly, A. R. (2016): Effects of municipal waste compost and nitrogen fertilizer on growth and mineral composition of tomato. - International Journal of Recycling of Organic Waste in Agriculture 5(4): 339-347.

[38] Saha, A. K., Carvalho, K. S., Sternberg, L. d. S. L., Moutinho, P. (2012): Effect of leafcutting ant nests on plant growth in an oligotrophic Amazon rain forest. - Journal of Tropical Ecology 28(3): 263-270.

[39] Saunders, L., Libardi, P., Reichardt, K. (1978): Condutividade hidráulica da terra roxa estruturada em condições de campo. - Revista Brasileira de Ciencia do Solo 2: 164-167.

[40] Schiøtt, M., De Fine Licht, H. H., Lange, L., Boomsma, J. J. (2008): Towards a molecular understanding of symbiont function: identification of a fungal gene for the degradation of xylan in the fungus gardens of leaf-cutting ants. - BMC Microbiology 8(1): 40.

[41] Shen, Y., Ren, L., Li, G., Chen, T., Guo, R. (2011): Influence of aeration on $\mathrm{CH}_{4}, \mathrm{~N}_{2} \mathrm{O}$ and $\mathrm{NH}_{3}$ emissions during aerobic composting of a chicken manure and high $\mathrm{C} / \mathrm{N}$ waste mixture. - Waste Management 31(1): 33-38.

[42] Silva-Pinhati, A. C. O., Bacci Jr, M., Hinkle, G., Sogin, M. L., Pagnocca, F. C., Martins, V. G., Bueno, O. C., Hebling, M. J. A. (2004): Low variation in ribosomal DNA and internal transcribed spacers of the symbiotic fungi of leaf-cutting ants (Attini: Formicidae). - Brazilian Journal of Medical and Biological Research 37(10): 1463-1472.

[43] Somera, A. F., Lima, A. M., dos Santos-Neto, Á. J., Lanças, F. M., Bacci, M. (2015): Leaf-cutter ant fungus gardens are biphasic mixed microbial bioreactors that convert plant 
biomass to polyols with biotechnological applications. - Applied and Environmental Microbiology 81(13): 4525-4535.

[44] Steiner, A. A. (1984): The Universal Nutrient Solution. - Proceedings of IWOSC 1984 6th International Congress on Soilless Culture, Wageningen.

[45] Sternberg, L. D. S. L., Pinzon, M. C., Moreira, M. Z., Moutinho, P., Rojas, E. I., Herre, E. A. (2007): Plants use macronutrients accumulated in leaf-cutting ant nests. - Proceedings of the Royal Society B: Biological Sciences 274(1608): 315-321.

[46] Tam, N. F. Y., Tiquia, S. M. (1999): Nitrogen transformation during co-composting of spent pig manure, sawdust litter and sludge under forced-aerated system. Environmental Technology 20(3): 259-267.

[47] Uzoma, K., Inoue, M., Andry, H., Zahoor, A., Nishihara, E. (2011): Influence of biochar application on sandy soil hydraulic properties and nutrient retention. - Journal of Food, Agriculture and Environment 9: 1137-1143.

[48] Wichuk, K. M., McCartney, D. (2010): Compost stability and maturity evaluation-a literature review. - Canadian Journal of Civil Engineering 37(11): 1505-1523.

[49] Yardimci, M. (2013): Waste to wealth strategies: recycling poultry manure. - Kocatepe Veterinary Journal 6(1): 69-72. 